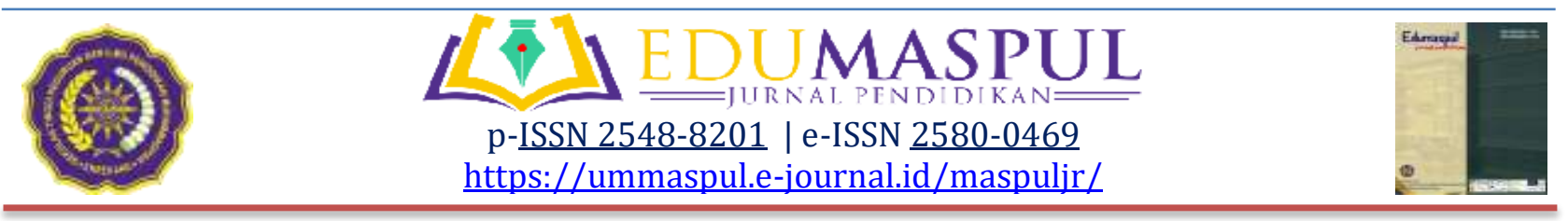

\title{
Pengembangan Instrumen Penilaian E-Quiz (Electronic Quiz) Matematika Berbasis Hots (Higher of Order Thinking Skills) untuk Kelas V Sekolah Dasar
}

\author{
Dian Fitri Nur Aini ${ }^{1}$, Nawang Sulistyani ${ }^{2}$ \\ 1-2PGSD, Universitas Muhammadiyah Malang, Malang, Indonesia \\ $\triangle$ Corresponding email: $\underline{1 \text { dian.fnai@gmail.com }}$
}

\begin{abstract}
Receive: 21-09-2019
Accepted: 30-09-2019

Published: 02-10-2019

Abstrak. Penelitian ini bertujuan untuk (1) menghasilkan instrumen penilaian e-quiz matematika berbasis HOTS (high order thinking skills) untuk kelas V SD, (2) mendeskripsikan kelayakan instrumen penilaian equiz matematika berbasis HOTS (high order thinking skills) untuk kelas V SD. Desain penelitian ini menggunakan desain penelitian pengembangan model Lee and Owens yang terdiri dari lima tahapan, yaitu; (1) Assesment/ Analysis yang terdiri dari dua bagian utama yaitu Analisis Kebutuhan dan Analisis Front-end; (2) Desain (Design); (3) Pengembangan (Development); (4) Penerapan (Implementation); dan (5) Evaluasi (Evaluation). Teknik pengumpulan data menggunakan teknik observasi, dokumentasi dan angket. Analisis data dalam penelitian ini yaitu analisis deskriptif kualitatif dan kuantitatif. Hasil penelitian menunjukkan bahwa produk hasil pengembangan memenuhi aspek kevalidan dengan nilai koefisien validasi sebesar $86,5 \%$. Hasil uji coba lapangan memeroleh persentase kepraktisan produk sebesar $90 \%$. Instrumen penilaian e-quiz berbasis HOTS (high order thinking skills) yang dikembangkan pada penelitian ini telah layak digunakan dalam penilaian pembelajaran khususnya pada mata pelajaran matematika karena telah memenuhi kriteria kevalidan dan kepraktisan.
\end{abstract}

Kata Kunci: Instrumen penilaian, Pembelajaran matematika, high order thinking skills.

\begin{abstract}
The purpose of this study is to (1) produce a mathematical e-quiz assessment instrument based on HOTS (high order thinking skills) for grade $V$ elementary school, (2) describe the feasibility of a mathematical equiz assessment instrument based on HOTS (high order thinking skills) for grade V SD. This research design uses the Lee and Owens development research model which consists of five stages, namely; (1) Assessment / Analysis which consists of two main parts namely Requirement Analysis and Front-end Analysis; (2) Design (Design); (3) Development (Development); (4) Implementation (Implementation); and (5) Evaluation. Data collection techniques using observation, documentation and questionnaires. Analysis of the data in this study is descriptive qualitative and quantitative analysis. The results showed that the product of the development met the validity aspect with a validation coefficient of $86,5 \%$. The field trial results obtained a percentage of product practicality of $90 \%$. HOTS (high order thinking skills) based e-quiz assessment instruments developed in this study were appropriate for use in learning assessments especially in mathematics because they met the criteria of validity and practicality.
\end{abstract}

Keywords: Assessment instruments, Mathematics learning, high order thinking skills. 


\section{PENDAHULUAN}

Perkembangan zaman di abad 21 ditandai dengan perkembangan teknologi di segala lini kehidupan masyarakat. Integrasi teknologi dalam kehidupan masyarakat saat ini melalui teknologi yang berkembang telah mengubah pola pikir, cara bekerja dan kehidupan masyarakat (Grabe, 2007). Perkembangan teknologi yang semakin pesat berdampak langsung pada bidang Pendidikan, khususnya dalam proses pembelajaran. Lembaga Pendidikan diharapkan mempersiapkan peserta didik untuk mengikuti perkembangan yang terjadi dengan mengintegrasikan teknologi dalam pembelajarannya (Ghavifekr, et.al, 2012). Perubahan yang terjadi pada abad 21 ini juga menjadi tantangan bagi guru yang merupakan salah satu subyek dalam pembelajaran. Secara langsung, guru dituntut untuk memiliki keahlian dalam berteknologi guna meningkatkan proses pembelajaran. Hal ini sejalan dengan pendapat Arnseth, et. al (2012) yang menjelaskan bahwa guru dipandang sebagai kunci utama dalam menerapkan pembelajaran berbasis teknologi pada pembelajaran abad 21 dengan menyediakan lingkungan belajar yang dinamis dan proaktif.

Salah satu kegiatan dalam proses pembelajaran yang harus dilakukan oleh guru adalah penilaian. Kegiatan penilaian bertujuan untuk mengetahui capaian hasil belajar serta efektifitas pelaksanaan pembelajaran yang dapat meningkatkan kualitas proses dan hasil pembelajaran (Arikunto, 2009). Proses penilaian memegang peranan penting dalam pembelajaran. Fungsi penting dari penilaian peserta didik bagi guru adalah memberikan umpan balik terhadap pembelajaran yang telah dilakukan oleh peserta didik di dalam maupun diluar kelas (Wahidmurni, dkk, 2010). Penilaian yang dilakukan guru pada peserta didik harus memenuhi beberapa prinsip yang dijabarkan oleh Anderson (2003) antara lain (1) meaningfulness (bermakna), penilaian yang telah dilakukan oleh guru harus memfokuskan pada makna dibalik peserta didik mendapatkan nilai tersebut, (2) expicitness (transparansi), pihak yang membutuhkan selain peserta didik berhak mendapatkan informasi berkaitan dengan penilaian yang telah dilakukan oleh guru. Transparansi penilaian bertujuan sebagai bahan pertimbangan guru untuk menentukan penilaian peserta didik dari beberapa kegiatan pembelajaran yang telah dilakukannya, (3) fairness (adil), setiap peserta didik berhak mendapatkan penilaian yang sama berdasarkan kemampuan yang dimiliki oleh peserta didik tersebut. Hasil penilaian yang diperoleh oleh guru dilakukan melalui proses procedural dan menggunakan alat penilaian yang valid dan reliabel.

Matematika merupakan salah satu mata pelajaran pada pembelajaran di Sekolah Dasar. Pelaksanaan pembelajaran matematika di tingkat Sekolah Dasar dimulai dari kelas I sampai kelas VI. Pada kurikulum 2013 yang menerapkan pembelajaran tematik, matematika untuk tingkatan kelas rendah yaitu kelas 1-3 pembelajarannya terintegrasi dengan mata pelajaran yang lain. Sedangkan pada 
tingkatan kelas tinggi yaitu kelas 4 sampai 6, matematika diberikan secara terpisah dengan mata pelajaran lain dalam pembelajaran.

Guru dapat menerapkan evaluasi dengan memanfaatkan perkembangan teknologi melalui sebuah aplikasi berbasis teknologi. Salah satu instrumen evaluasi berbasis teknologi yang dapat drancang oleh guru adalah e-quiz. e-quiz merupakan serangkaian jenis tes yang disajikan dengan memanfaatkan perangkat elektronik berupa komputer atau laptop. equiz dilengkapi dengan teks, gambar video dan audio yang menarik. Dalam e-quiz guru dapat mengembangkan bermacammacam jenis soal dan penilaian dapat diberikan secara langsung secara otomatis. Penggunaan e-quiz merupakan salah satu penerapan proses evaluasi berbasis teknologi.

Perkembangan teknologi secara langsung juga berpengaruh pada kemampuan pengguna teknologi dalam pembelajaran yaitu guru dan peserta didik. Pembelajaran abad 21 mengharuskan guru dan peserta didik untuk memiliki ketrampilan belajar yang disebut dengan 4C, yaitu (1) communication, collaboration, (3) critical thinking, (4) creative dan innovative. Pencapaian 4 keterampilan belajar tersebut dapat dilakukan melalui pembelajaran HOTS (high order thinking skills) atau kemampuan berpikir tingkat tinggi. Anderson \& Krathwohl menjelaskan bahwa kemampuan berpikir tingkat tinggi dalam Taksonomi Bloom secara umum digunakan untuk mengukur kemampuan pada ranah menganalisis (C4), mengevaluasi (C5), dan mengkreasi (C6). Peserta didik diwajibkan mampu memiliki kompetensi berpikir tingkat tinggi agar mampu bersaing dalam perkembangan pada abad 21. Salah satu cara memfasilitasi kebutuhan peserta didik meningkatkan kemampuan berpikir tingkat tinggi melalui penggunaan soalsoal HOTS. Soal-soal HOTS digunakan sebagai parameter untuk mengukur kemampuan berpikir tingkat tinggi. Kemampuan berpikir tingkat tinggi tidak sekedar mengingat (recall), menyatakan kembali (restate), atau merujuk tanpa melakukan pengolahan (recite). Soal-soal HOTS pada konteks asesmen mengukur kemampuan: 1) transfer satu konsep ke konsep lainnya, 2) memproses dan menerapkan informasi, 3) mencari kaitan dari berbagai informasi yang berbedabeda, 4) menggunakan informasi untuk menyelesaikan masalah, dan 5) menelaah ide dan informasi secara kritis. Soal-soal HOTS dapat diimplementasikan guru pada soal ujian dalam bentuk E-quiz.

SD Muhammadiyah 5 Kota Malang merupakan salah satu SD swasta di Kota Malang yang memiliki sarana prasarana mendukung. Namun SD Muhammadiyah 5 Kota Malang belum memanfaatkan secara masimal sarana prasarana yang sudah dimilikinya. Kegiatan penilaian dilakukan dengan menggunakan perangkat instrument paper based test dan belum menggunakan penilaian secara online. Berdasarkan permasalahan yang dialami oleh SD Muhammadiyah 5 Kota Malang, terlihat bahwa e-quiz berbasis HOTS 
merupakan salah satu kunci meningkatkan penilaian pembelajarannya.

Berdasarkan identifikasi permasalahan serta beberapa penelitian relevan yang telah dijabarkan maka perlu dilakukan pengembangan instrumen penilaian e-quiz matematika berbasis HOTS (high order thinking skills) pada kelas $\mathrm{V}$ di SD Muhammadiyah 5 Kota Malang. Hal ini bertujuan sebagai inovasi dalam proses penilaian dengan memanfaatkan fasilitas berbasis teknologi yang sudah tersedia di sekolah. Selain itu, pengembangan instrumen penilaian e-quiz matematika berbasis HOTS (high order thinking skills) untuk mengukur kemampuan berpikir tingkat tinggi peserta didik dalam mengidentifikasi soal HOTS (high order thinking skills). Disamping itu, penggunaan instrument penilaian berbasis teknologi juga memberikan manfaat dilihat dari nilai praktis, ekonomis dan kemudahan dalam pelaksanaan proses pembelajaran khususnya kegiatan penilaian di sekolah.

\section{METODE}

Penelitian ini merupakan penelitian dan pengembangan (Research and Development) dengan menggunakan model pengembangan Lee and Owens (2004). Adapun langkah pengembangan Lee and Owens, yaitu: (1) Assesment/ Analysis yang terdiri dari dua bagian utama yaitu Analisis Kebutuhan dan Analisis Front-end; (2) Desain (Design); (3) Pengembangan (Development); (4) Penerapan (Implementation); (5) Evaluasi (Evaluation). Adapun prosedur penelitian dan pengembangan disajikan pada Gambar 1 berikut.

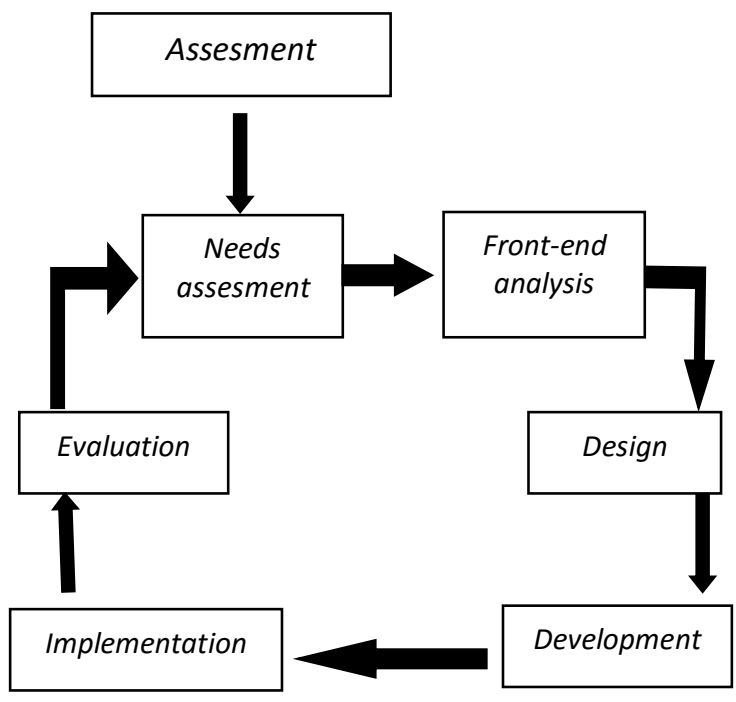

Gambar 1. Model Lee dan Owens (2004: xxviii)

Sesuai dengan jenis penelitian yang digunakan, sumber data dalam penelitian ini diperoleh dari sumber data primer dan sumber data sekunder. Sumber data primer diperoleh dari para informan yang dianggap paling penting dalam mengetahui secara rinci dan jelas mengenai fokus penelitian. Informan tersebut adalah Guru kelas dan seluruh siswa kelas V SD Muhammadiyah 5 Kota Malang. Sedangkan sumber data sekunder diperoleh melalui studi observasi terhadap pelaksanaan pembelajaran dan dokumentasi yang berupa foto kegiatan pembelajaran, serta data pendukung lainnya. Peneliti menggunakan tiga teknik untuk memeroleh data di lapangan, yaitu: teknik observasi, dokumentasi dan angket. Analisis data dalam penelitian ini yaitu analisis deskriptif kualitatif dan kuantitatif. Teknik analisis deskriptif kualitatif digunakan untuk menganalisis data dari hasil validasi ahli dan pengguna. 
Edumaspul: Jurnal Pendidikan, 3 (2), 2019 - 5 Dian Fitri Nur Aini \& Nawang Sulistyani

Sedangkan analisis kuantitatif digunakan untuk menganalisis data yang diperoleh dari skor angket. Ada dua analisis deskriptif kuantitatif yang digunakan oleh peneliti, yaitu: (1) Analisis data kevalidan produk dan (2) Analisis data Kepraktisan produk. Data kevalidan produk diperoleh melalui hasil validasi ahli yang berupa instrumen angket. Rumus yang digunakan untuk mengetahui nilai kevalidan produk yaitu:

$$
V=\frac{T S h}{T S e} \times 100 \%
$$

Keterangan $: \mathrm{V}=$ Validitas, $\mathrm{TSh}=$ Total Skor maksimal yang diharapkan, Tse $=$ Total Skor Empiris (hasil validasi dari validator) (Sumber: Akbar, 2013: 158).

Setelah diketahui nilai validasinya, untuk mendeskripsikan hasil validasi tersebut dapat dilihat dari kriteria validasi pada Tabel 1 berikut.

\section{Tabel 1. Kriteria Kevalidan Produk}

\begin{tabular}{|c|c|c|c|}
\hline No & $\begin{array}{l}\text { Kriteria } \\
\text { Validasi }\end{array}$ & $\begin{array}{c}\text { Kategori } \\
\text { Tingkat } \\
\text { Validitas }\end{array}$ & Keterangan \\
\hline 1 & $\begin{array}{l}85,01- \\
100 \%\end{array}$ & $\begin{array}{l}\text { Sangat } \\
\text { Valid }\end{array}$ & $\begin{array}{l}\text { Dapat } \\
\text { digunakan }\end{array}$ \\
\hline 2 & $\begin{array}{l}70,01- \\
85,00 \%\end{array}$ & Valid & $\begin{array}{l}\text { Dapat } \\
\text { digunakan } \\
\text { dengan revisi } \\
\text { kecil }\end{array}$ \\
\hline 3 & $\begin{array}{l}50,01- \\
70,00 \%\end{array}$ & $\begin{array}{c}\text { Kurang } \\
\text { Valid }\end{array}$ & $\begin{array}{l}\text { Disarankan } \\
\text { untuk tidak } \\
\text { dipergunakan }\end{array}$ \\
\hline 4 & $\begin{array}{l}01,00- \\
50,00 \%\end{array}$ & $\begin{array}{l}\text { Tidak } \\
\text { Valid }\end{array}$ & $\begin{array}{l}\text { Tidak dapat } \\
\text { digunakan }\end{array}$ \\
\hline
\end{tabular}

Data tentang tingkat kepraktisan produk dapat diperoleh dari hasil instrumen angket tanggapan siswa. Adapun perhitungan data tersebut adalah sebagai berikut:

$$
\mathrm{KPr}=\frac{T S-e}{T S m} \times 100 \%
$$

Keterangan: $\mathrm{KPr}=$ Kepraktisan, $\mathrm{TS}-\mathrm{e}=$ Total skor empiric, TSm = Total skor maksimal (Sumber: Akbar \& Sriwiyana (2011: 207)).

Adapun kriteria yang digunakan untuk mengetahui kepraktisan e-quiz Matematika berbasis HOTS dapat dilihat pada Tabel 2 berikut.

\begin{tabular}{|c|c|c|c|}
\hline No & $\begin{array}{l}\text { Kriteria } \\
\text { Validasi }\end{array}$ & $\begin{array}{c}\text { Kategori } \\
\text { Tingkat } \\
\text { Validitas }\end{array}$ & Keterangan \\
\hline 1 & $\begin{array}{l}85,01- \\
100 \%\end{array}$ & $\begin{array}{l}\text { Sangat } \\
\text { Praktis }\end{array}$ & $\begin{array}{l}\text { Dapat } \\
\text { digunakan }\end{array}$ \\
\hline 2 & $\begin{array}{l}70,01- \\
85,00 \%\end{array}$ & Praktis & $\begin{array}{l}\text { Dapat } \\
\text { digunakan } \\
\text { dengan revisi } \\
\text { kecil }\end{array}$ \\
\hline 3 & $\begin{array}{l}50,01- \\
70,00 \%\end{array}$ & $\begin{array}{l}\text { Kurang } \\
\text { Praktis }\end{array}$ & $\begin{array}{l}\text { Disarankan } \\
\text { untuk tidak } \\
\text { dipergunakan }\end{array}$ \\
\hline 4 & $\begin{array}{l}01,00- \\
50,00 \%\end{array}$ & $\begin{array}{c}\text { Tidak } \\
\text { Praktis }\end{array}$ & $\begin{array}{l}\text { Tidak dapat } \\
\text { digunakan }\end{array}$ \\
\hline
\end{tabular}

Tabel 2. Kriteria Kepraktisan Produk

\section{HASIL DAN PEMBAHASAN}

Hasil penelitian pengembangan ini yaitu produk yang berupa Intrumen Penialain HOTS pada pembelajaran Matematika. Adapun hasil dari produk pengembangan dapat disajikan pada gambar 2 berikut.

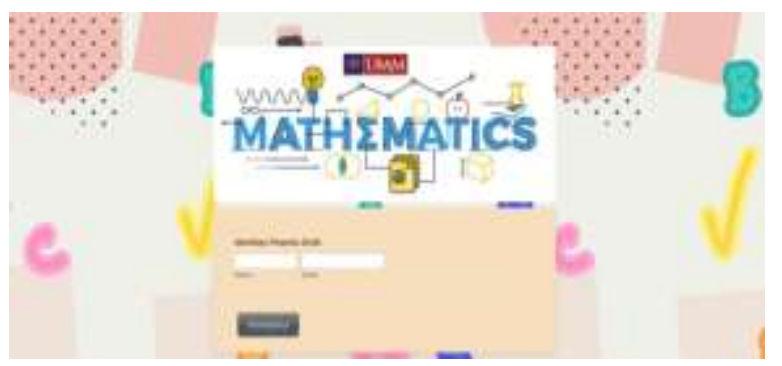

Gambar 2. e-quiz berbasis HOTS 
Langkah yang dilakukan oleh peneliti untuk pengembangan Intrumen Penialain HOTS pada pembelajaran matematika yaitu:

\section{Assesment/Analysis yang terdiri dari dua bagian utama yaitu Analisis Kebutuhan dan Analisis Front-end}

Masalah yang telah ditemukan peneliti dalam studi lapangan meliputi: (1) belum memanfaatkan secara masimal sarana prasarana yang sudah dimiliki sekolah, (2) penilaian pembelajaran dilakukan dengan menggunakan perangkat instrumen paper based test dan belum menggunakan penilaian secara online, (3) guru membutuhkan inovasi penilaian pembelajaran sesuai tuntutan penialaian HOTS. Berdasarkan masalah yang ditemukan, peneliti mengidentifikasi kebutuhan yang harus segera diselesaikan yaitu guru dan siswa membutuhkan intrumen penilaian pembelajaran yang berbasis HOTS. Instrumen penilaian tersebut diharapkan sebagai inovasi dalam proses penilaian dengan memanfaatkan fasilitas berbasis teknologi yang sudah tersedia di sekolah.

\section{Desain (Design)}

Kegiatan yang dilakukan pada tahap ini yaitu merancang jadwal memulai pengembangan e-quiz berbasis HOTS yang dilaksanakan pada bulan Maret s.d Agustus 2019. Adapun kegiatan yang dilakukan meliputi pengumpulan data untuk pengembangan e-quiz, membuat rancangan e-quiz, mengembangkan produk e-quiz, uji coba untuk memvalidasi oleh ahli materi dan ahli bahasa, revisi produk yang telah divalidasi dan diberikan saran oleh validator, serta uji coba produk.

\section{Pengembangan (Development)}

Instrumen penilaian yang dikembangkan tidak hanya berfokus pada penilaian kognitif saja, melainkan juga afektif dan psikomotor. Selain itu, instrumen penilaian juga disesuaiakan dengan ranah kognitif C4-C6 dari taksonomi Bloom yang telah disempurnakan oleh Anderson dan Krathwohl (Arends, 2012) yang meliputi: analyze/ menganalisa (C4), evaluate/ mengevaluasi (C5), dan create/ mencipta (C6). Adapun produk yang dikembangkan berupa instrumen penilaian e-quiz yang bisa diakses oleh seluruh siswa didalamnya memuat identitas siswa, petunjuk ujian, kompetensi dasar, tujuan pembelajaran, soal evaluasi, dan skor.

\section{Penerapan (Implementation)}

E-quiz yang telah dikembangkan peneliti telah diujicobakan kepada ahli materi dan ahli bahasa. Hasil uji coba ahli direvisi untuk menyempurnakan produk sebelum diujicobakan kepada siswa. Adapun data kevalidan dan kepraktisan produk akan diuraikan sebagai berikut.

\section{a. Data Kevalidan Produk}

Data kevalidan produk diperoleh peneliti dari hasil validasi ahli materi dan ahli bahasa. Adapun data hasil uji coba validasi ahli akan diuraikan sebagai berikut.

\section{1) Validasi ahli materi}

Materi pembelajaran yang terdapat dalam e-quiz ini yaitu menentukan volume bangun ruang. Adapun data hasil validasi 
Edumaspul: Jurnal Pendidikan, 3 (2), 2019 - 7 Dian Fitri Nur Aini \& Nawang Sulistyani

ahli materi disajikan pada Tabel 1.3 berikut.

Tabel 3. Data Validasi Ahli Materi

\begin{tabular}{|c|c|c|c|c|c|}
\hline \multirow[b]{2}{*}{ No } & \multirow{2}{*}{$\begin{array}{l}\text { Aspek yang } \\
\text { dinilai }\end{array}$} & \multicolumn{2}{|c|}{ Skor } & \multirow{2}{*}{$\begin{array}{l}\text { Perse } \\
\text { ntase }\end{array}$} & \multirow[b]{2}{*}{ Kriteria } \\
\hline & & $\begin{array}{c}\text { Perole } \\
\text { han }\end{array}$ & $\begin{array}{c}\text { Maksi } \\
\text { mal }\end{array}$ & & \\
\hline 1 & Relevansi & 16 & 16 & $100 \%$ & $\begin{array}{c}\text { Sangat } \\
\text { valid }\end{array}$ \\
\hline 2 & Ketepatan & 23 & 24 & $96 \%$ & $\begin{array}{c}\text { Sangat } \\
\text { valid }\end{array}$ \\
\hline 3 & $\begin{array}{l}\text { Kesesuaian } \\
\text { dengan } \\
\text { Prinsip-prinsip } \\
\text { Pembelajaran }\end{array}$ & 19 & 20 & $95 \%$ & $\begin{array}{c}\text { Sangat } \\
\text { valid }\end{array}$ \\
\hline 4 & $\begin{array}{l}\text { Student } \\
\text { Centered }\end{array}$ & 19 & 20 & $95 \%$ & $\begin{array}{c}\text { Sangat } \\
\text { valid }\end{array}$ \\
\hline 5 & $\begin{array}{l}\text { Prinsip } \\
\text { Pendekatan } \\
\text { Saintifik 5M }\end{array}$ & 19 & 20 & $95 \%$ & $\begin{array}{c}\text { Sangat } \\
\text { valid }\end{array}$ \\
\hline 6 & $\begin{array}{l}\text { Pembentukan } \\
\text { sikap }\end{array}$ & 24 & 24 & $100 \%$ & $\begin{array}{c}\text { Sangat } \\
\text { valid }\end{array}$ \\
\hline 7 & Evaluasi & 15 & 16 & $94 \%$ & $\begin{array}{c}\text { Sangat } \\
\text { valid }\end{array}$ \\
\hline & $\begin{array}{l}\text { Total Skor } \\
\text { Penilaian }\end{array}$ & 135 & 140 & $96 \%$ & $\begin{array}{c}\text { Sangat } \\
\text { valid }\end{array}$ \\
\hline
\end{tabular}

Berdasarkan tabel 3. di atas dapat dilihat bahwa skor perolehan dari validasi ahli materi sebesar 135 dari skor maksimal sebesar 140. Persentase kevalidan produk sebesar 96\%. Hal ini dapat ditafsirkan bahwa produk dalam kriteria sangat valid. Validator ahli materi menyampaikan bahwa secara umum isi equiz berbasis HOTS yang dikembangkan sudah sesuai dengan KD Matematika kurikulum 2013 pada jenjang kelas V SD. Namun, ada beberapa saran yang diberikan oleh ahli materi untuk memperbaiki e-quiz berbasis HOTS. Adapun saran tersebut yaitu (1) revisi tujuan pembelajaran, (2) font pada setiap soal diperbesar, dan (3) kalimat perintah pada soal sebaiknya diletakkan disetiap halaman soal.

\section{2) Validasi Ahli Bahasa}

Adapun data hasil validasi ahli bahasa

\begin{tabular}{|c|c|c|c|c|c|}
\hline \multirow[b]{2}{*}{ No } & \multirow[b]{2}{*}{$\begin{array}{l}\text { Aspek yang } \\
\text { dinilai }\end{array}$} & \multicolumn{2}{|c|}{ Skor } & \multirow[b]{2}{*}{$\begin{array}{l}\text { Persent } \\
\text { ase }\end{array}$} & \multirow[b]{2}{*}{ Kriteria } \\
\hline & & $\begin{array}{c}\text { Peroleha } \\
n\end{array}$ & $\begin{array}{c}\text { Maksim } \\
\text { al }\end{array}$ & & \\
\hline 1 & Lugas & 9 & 12 & $75 \%$ & Valid \\
\hline 2 & Komunikatif & 22 & 28 & $79 \%$ & Valid \\
\hline 3 & Kesesuaian & 15 & 20 & $75 \%$ & Valid \\
\hline & $\begin{array}{l}\text { Total Skor } \\
\text { Penilaian }\end{array}$ & 46 & 60 & $77 \%$ & Valid \\
\hline
\end{tabular}

Tabel 4. Data Validasi Ahli Bahasa

Berdasarkan tabel 4 di atas dapat disimpulkan bahwa skor perolehan dari validasi ahli bahasa sebesar 46 dari skor maksimal sebesar 60. Persentase kevalidan produk sebesar $77 \%$. Hal ini dapat ditafsirkan bahwa produk dalam kriteria valid. Validator bahasa juga memberikan saran untuk perbaikan yaitu (1) konsistensi dalam menyapa siswa (kalian atau kamu), sebaiknya gunakan kata "kalian", dan (2) lihat coretancoretan dan perbaikan di naskah seperti penggunaan tanda baca, spasi pada setiap kalimat.

Hasil akhir dari analisis kevalidan adalah gabungan antara hasil validasi ahli materi dan ahli bahasa. Analisis kevalidan e-quiz berbasis HOTS secara keseluruhan diperoleh hasil sebesar 86,5\%. Berdasarkan kriteria kevalidan, produk pengembangan tersebut dapat ditafsirkan dalam kriteria "sangat valid".

\section{b. Data Kepraktisan Produk}

Data kepraktisan produk diperoleh dari analisis data hasil angket respon siswa dan guru kelas V SD 
Edumaspul: Jurnal Pendidikan, 3 (2), 2019 - 8 Dian Fitri Nur Aini \& Nawang Sulistyani

Muhammadiyah 5 Kota Malang pada uji coba lapangan. Berikut data analisis respon siswa pada uji coba lapangan disajikan pada tabel 5 dan 6 .

Tabel 5. Analisis Respon Siswa Kelas V pada Uji Lapangan

\begin{tabular}{|c|c|c|c|c|c|}
\hline No & Nama & $\begin{array}{c}\text { Skor } \\
\text { Peroleh } \\
\text { an }\end{array}$ & $\begin{array}{c}\text { Skor } \\
\text { Maksi } \\
\text { mal }\end{array}$ & $\begin{array}{c}\text { Persent } \\
\text { ase }\end{array}$ & Kriteria \\
\hline 1. & $\mathrm{AOA}$ & 57 & 60 & $95 \%$ & Sangat Praktis \\
\hline 2. & APAR & 59 & 60 & $98 \%$ & Sangat Praktis \\
\hline 3. & AIR & 57 & 60 & $95 \%$ & Sangat Praktis \\
\hline 4. & ALAB & 59 & 60 & $98 \%$ & Sangat Praktis \\
\hline 5. & AGA & 59 & 60 & $98 \%$ & Sangat Praktis \\
\hline 6. & ADRK & 55 & 60 & $92 \%$ & Sangat Praktis \\
\hline 7. & BA & 58 & 60 & $97 \%$ & Sangat Praktis \\
\hline 8. & CCTR & 58 & 60 & $97 \%$ & Sangat Praktis \\
\hline 9. & DYA & 58 & 60 & $97 \%$ & Sangat Praktis \\
\hline 10. & FFA & 58 & 60 & $97 \%$ & Sangat Praktis \\
\hline 11. & JHK & 51 & 60 & $85 \%$ & Praktis \\
\hline 12. & MAP & 51 & 60 & $85 \%$ & Praktis \\
\hline 13. & MAA & 55 & 60 & $92 \%$ & Sangat Praktis \\
\hline 14. & MDR & 57 & 60 & $95 \%$ & Sangat Praktis \\
\hline 15. & NNA & 60 & 60 & $100 \%$ & Sangat Praktis \\
\hline 16. & NKD & 57 & 60 & $95 \%$ & Sangat Praktis \\
\hline 17. & NAFA & 54 & 60 & $90 \%$ & Sangat Praktis \\
\hline 18. & NAA & 60 & 60 & $100 \%$ & Sangat Praktis \\
\hline 19. & OSAA & 55 & 60 & $92 \%$ & Sangat Praktis \\
\hline 20. & RSF & 60 & 60 & $100 \%$ & Sangat Praktis \\
\hline 21. & WRA & 51 & 60 & $85 \%$ & Praktis \\
\hline 22. & YHK & 59 & 60 & $98 \%$ & Sangat Praktis \\
\hline 23. & ZWPP & 59 & 60 & $98 \%$ & Sangat Praktis \\
\hline 24. & ZFI & 59 & 60 & $98 \%$ & Sangat Praktis \\
\hline 25. & ZPP & 57 & 60 & $95 \%$ & Sangat Praktis \\
\hline 26. & MNN & 53 & 60 & $88 \%$ & Sangat Praktis \\
\hline 27. & SEP & 53 & 60 & $88 \%$ & Sangat Praktis \\
\hline 28. & BTD & 54 & 60 & $90 \%$ & Sangat Praktis \\
\hline 29. & DDM & 56 & 60 & $93 \%$ & Sangat Praktis \\
\hline 30. & ARS & 59 & 60 & $98 \%$ & Sangat Praktis \\
\hline \multicolumn{2}{|c|}{ Skor Total } & 1698 & 1800 & $2829 \%$ & Sangat Praktis \\
\hline \multicolumn{2}{|c|}{ Rata-rata } & 57 & 60 & $94 \%$ & Sangat Praktis \\
\hline
\end{tabular}

Berdasarkan hasil analisis respon siswa dapat disimpulkan bahwa secara umum siswa memberikan penilaian pada kriteria "sangat praktis". Akan tetapi terdapat 3 orang siswa yang memberikan penilaian dengan kriteria "praktis". Selain data analisis respon siswa, berikut ini akan dipaparkan data analisis respon guru pada uji coba lapangan. Data dipaparkan pada 6 berikut ini.

\section{Tabel 6. Analisis Respon Guru pada Uji Coba Lapangan}

\begin{tabular}{|c|c|c|c|c|c|}
\hline \multirow{2}{*}{ No } & \multicolumn{2}{|c|}{$\begin{array}{l}\text { Aspek yang } \\
\text { dinilai }\end{array}$} & Skor & \multirow{2}{*}{$\%$} & \multirow{2}{*}{ Kriteria } \\
\hline & & $\begin{array}{l}\text { Peroleh } \\
\text { an }\end{array}$ & $\begin{array}{c}\text { Maksi } \\
\text { mal }\end{array}$ & & \\
\hline 1 & Bahasa & 7 & 8 & $87 \%$ & $\begin{array}{l}\text { Sangat } \\
\text { praktis }\end{array}$ \\
\hline 2 & Materi dan isi & 14 & 16 & $87 \%$ & $\begin{array}{l}\text { Sangat } \\
\text { praktis }\end{array}$ \\
\hline 3 & Sajian soal & 22 & 24 & $92 \%$ & $\begin{array}{l}\text { Sangat } \\
\text { Praktis }\end{array}$ \\
\hline 4 & $\begin{array}{l}\text { Pelaksanaan } \\
\text { pembelajaran }\end{array}$ & 10 & 12 & $83 \%$ & Praktis \\
\hline \multicolumn{2}{|c|}{ Skor Total } & 53 & 60 & $87 \%$ & $\begin{array}{l}\text { Sangat } \\
\text { praktis }\end{array}$ \\
\hline
\end{tabular}

Berdasarkan paparan data pada tabel 6 dapat disimpulkan bahwa persentase semua aspek menunjukkan kriteria "sangat praktis". Akan tetapi pada aspek pelaksanaan pembelajaran menunjukkan kriteria "praktis". Hal itu dapat diartikan bahwa pada aspek pelaksanaan pembelajaran terdapat kekurangan jika dibandingkan dengan aspek yang lainnya. Hasil akhir dari analisis kepraktisan adalah gabungan antara hasil respon siswa dan respon guru. Adapun hasil analisis kepraktisan produk e-quiz berbasis kearifan HOTS akan dipaparkan pada Tabel 7 berikut.

Tabel 7. Analisis Gabungan Aspek Kepraktisan

\begin{tabular}{llll}
\hline No & Subyek & $\begin{array}{l}\text { Hasil } \\
\text { Persentase } \\
\text { perolehan }\end{array}$ & Kriteria \\
\hline 1. & $\begin{array}{l}\text { Respon } \\
\text { Siswa } \\
\text { Respon } \\
\text { Guru }\end{array}$ & $94 \%$ & Sangat praktis \\
\hline Skor Total & $181 \%$ & Sangat praktis \\
\hline \multicolumn{2}{l}{ Rata-rata } & $90 \%$ & Sangat praktis \\
\hline
\end{tabular}


Berdasarkan tabel 7 dapat disimpulkan bahwa analisis kepraktisan bahan ajar berbasis kearifan lokal Kota Batu secara keseluruhan diperoleh hasil sebesar 90\%. Berdasarkan kriteria kepraktisan, produk pengembangan tersebut dapat ditafsirkan dalam kriteria "sangat praktis".

\section{Evaluasi (Evaluation)}

Tahap evaluasi ini dilakukan pengumpulan data hasil validasi ahli dan uji coba guru dan siswa. Hasil data dievaluasi sebagai dasar menentukan equiz layak digunakan sebagai instrumen penilaian dalam pembelajaran matematika serta membantu dalam mencapai tujuan pembelajaran yang diinginkan. Evaluasi ini dianalisis untuk mengukur tingkat pencapaian materi dan keterampilan dari aktivitas pembelajaran yang telah dilakukan, serta mengukur sikap siswa sebagai hasil dari pengetahuan dan keterampilan yang dilakukan.

\section{KESIMPULAN}

Instrumen penilaian e-quiz berbasis HOTS (high order thinking skills) yang dikembangkan pada penelitian ini telah layak digunakan dalam penilaian pembelajaran khususnya pada mata pelajaran matematika karena telah memenuhi kriteria kevalidan dan kepraktisan. Berdasarkan rata-rata hasil validasi ahli materi, bahasa dan desain, kevalidan produk sebesar 86,5\%. Berdasarkan rata-rata hasil uji coba lapangan persentase kepraktisan produk sebesar 90\%. Hal ini menunjukkan bahwa produk yang telah dikembangkan sudah sesuai dengan kriteria yang telah ditentukan oleh peneliti yaitu sangat valid secara teoritik, dan sangat praktis digunakan oleh guru sebagai instrument penilaian pembelajaran.

\section{Daftar Pustaka}

[1] Akbar, Sa'dun., Sriwiyana. (2011). Pengembanagn Kurikulum dan Pembelajaran IPS. Yogyakarta: Cipta Media.

[2] Akbar, Sa'dun. (2013). Instrumen Perangkat Pembelajaran. Bandung: PT. Remaja Rosdakarya.

[3] Anderson, L. W. (2003). Classroom assessment: Enhanching the quality of teacher decision making. New Jersey: Lawrence Erl-baum Associates Inc.

[4] Arikunto, S. (2009). Dasar-Dasar Evaluasi Pendidikan. Jakarta: PT Bumi Aksara.

[5] Arnseth, H.C., \& Hatlevik, O.E. (2010). Challenges in aligning pedagogical practices and pupils' competencies with the Information Society's demands: The case of Norway. In S. Mukerji \& P.

[6] Ghavifekr, S., Afshari, M., \& Amla Salleh. (2012). Management strategies for ELearning system as the core component of systemic change: A qualitative analysis. Life Science Journal, 9(3), 21902196.

[7] Grabe, M., \& Grabe, C. (2007). Integrating technology for meaningful learning (5th ed.). Boston, MA: Houghton Mifflin

[8] Lee, W. \& Owens, D, L. (2004). Multimedia Based Instructional Design, Second Edition. United States of Amrica: John Wiley \& Sonc. Inc.

[9] Triphati (Eds.),. (2010). Cases on technological adaptability and transnational learning: Issues and challenges. Hershey: IGI global.

[10] Wahidmurni, dkk. (2010). Evaluasi Pembelajaran. Yogyakarta: Nuha Litera

Profil Penulis

Penulis pertama yaitu Dian Fitri Nur Aini, M.Pd merupakan seorang dosen di PGSD Universitas Muhammadiyah Malang. Penulis lahir di Blitar, 22 Januari 1989. Pendidikan Sarjana 
Edumaspul: Jurnal Pendidikan, 3 (2), 2019 - 10 Dian Fitri Nur Aini \& Nawang Sulistyani

ditempuh di Universitas Muhammadiyah Malang dengan mengambil jurusan PGSD. Pada jenjang Magister, penulis melanjutkan pendidikannya di Universitas Negeri Malang dengan mengambil jurusan yang linier yaitu Pendidikan Dasar (Dikdas). Saat ini penulis tercatat sebagai dosen di Universitas Muhammadiyah Malang.

Penulis kedua yaitu Nawang Sulistyani, M.Pd. Penulis lahir di Bojonegoro, 30 Januari 1994.
Pendidikan Sarjana ditempuh penulis di Universitas Muhammadiyah Malang dengan jurusan PGSD. Pada jenjang Magister, penulis mengambil jurusan Pendidikan Dasar (Dikdas) di Universitas Negeri Malang. Saat ini penulis aktif sebagai dosen di Universitas Muhammadiyah Malang. 